\title{
Recombinant biosynthesis of bacterial cellulose in genetically modified Escherichia coli
}

\author{
Gizem Buldum $^{1,4} \cdot$ Alexander Bismarck $^{2,3} \cdot$ Athanasios Mantalaris $^{1}$
}

Received: 4 July 2017 / Accepted: 4 November 2017 / Published online: 24 November 2017

(C) The Author(s) 2017. This article is an open access publication

\begin{abstract}
Bacterial cellulose (BC) exhibits unique properties such as high purity compared to plant-based cellulose; however, commercial production of $\mathrm{BC}$ has remained a challenge, primarily due to the strain properties of cellulose-producing bacteria. Herein, we developed a functional and stable BC production system in genetically modified (GM) Escherichia coli by recombinant expression of both the $\mathrm{BC}$ synthase operon (bcs $\mathrm{ABCD}$ ) and the upstream operon ( $c m c a x, c c p A x)$. $\mathrm{BC}$ production was achieved in GM HMS174 (DE3) and in GM C41 (DE3) by optimization of the culture temperature $\left(22^{\circ} \mathrm{C}, 30^{\circ} \mathrm{C}\right.$, and $\left.37^{\circ} \mathrm{C}\right)$ and IPTG concentration. BC biosynthesis was detected much earlier in GM C41 (DE3) cultures ( $3 \mathrm{~h}$ after IPTG induction) than those of Gluconacetobacter hansenii. GM HMS174 (DE3) produced dense fibres having a length of approximately 1000-3000 $\mu \mathrm{m}$ and a diameter of 10-20 $\mu \mathrm{m}$, which were remarkably larger than the fibres of BC typically produced by G. hansenii.
\end{abstract}

Keywords Bacterial cellulose $\cdot$ Escherichia coli $\cdot$ Recombinant biosynthesis $\cdot$ Optimization of culture conditions $\cdot$ Plasmid maintenance

\section{Abbreviations}

$\mathrm{BC}$

$B c s$

$\mathrm{Bp}$

Bacterial cellulose

Bacterial cellulose synthesis

Base pair

Electronic supplementary material The online version of this article (https://doi.org/10.1007/s00449-017-1864-1) contains supplementary material, which is available to authorized users.

Athanasios Mantalaris

a.mantalaris@imperial.ac.uk

Gizem Buldum

g.buldum11@imperial.ac.uk

Alexander Bismarck

a.bismarck@imperial.ac.uk

1 Biological Systems Engineering Laboratory (BSEL), Department of Chemical Engineering, Imperial College London, South Kensington Campus, London SW7 2AZ, UK

2 Polymer and Composite Engineering (PaCE) Group, Department of Chemical Engineering, Imperial College London, South Kensington Campus, London SW7 2AZ, UK

3 Polymer and Composite Engineering (PaCE) Group, Institute of Materials Chemistry and Research, Faculty of Chemistry, University of Vienna, Währinger Str. 42, 1090 Vienna, Austria

4 Department of Bioengineering, Marmara University, Göztepe Campus, Istanbul, Turkey

$\begin{array}{ll}\text { DCW } & \text { Dry cell weight } \\ \text { FTIR } & \text { Fourier transform infrared } \\ \text { GM } & \text { Genetically modified } \\ \text { IPTG } & \text { Isopropyl } \beta \text {-D-1-thiogalactopyranoside } \\ \text { KU } & \text { Kilo unit } \\ \text { Kbp } & \text { Kilo base pair } \\ \text { LB Medium } & \text { Lysogeny broth medium } \\ \text { q-PCR } & \text { Quantitative polymerase chain reaction } \\ \text { RQ } & \text { Relative quantification } \\ \text { SEM } & \text { Scanning electron microscopy }\end{array}$

\section{Introduction}

Bacterial cellulose (BC) is a biomaterial with unique properties and receiving a growing attention for industrial applications. BC has many advantages over plant-based cellulose such as high purity, which allows a purification process that is straightforward [1, 2]. In addition, it exhibits excellent mechanical and chemical properties including a high crystallinity, high tensile strength, high water holding capacity, high modulus of elasticity, and biocompatibility [3-5]. These properties enable BC to be used in a wide range of industrial applications such as medical products, electronics, paper, food, and cosmetics. BC provides 
all requirements for wound dressing material such as high porosity and providing a barrier against infection [6, 7].

Currently, plant-derived cellulose has a significant economic value with $\$ 200$ billion per year worldwide. In 2016, the price of wood pulp, the main source of plantbased cellulose, was as low as $\$ 0.96$ per $\mathrm{kg}$. However, the extraction process of cellulose from wood causes both environmental hazards and requires high energy [8]. Recent developments have demonstrated the use of cellulose-producing bacteria to alleviate the demand on plant cellulose; nonetheless, the average cost of bacterial cellulose remains at $\$ 35$ per pound ( $\$ 77$ per $\mathrm{kg}$ ), which is still 80 times higher than plant-derived cellulose [9].

Gluconacetobacter hansenii (formerly known as Gluconacetobacter xylinus) is the most efficient BC producer among cellulose producer species [10]. Biosynthesis of cellulose is encoded by the bacterial cellulose synthesis (bcs) operon in G. hansenii. This operon is essential for a complete $\mathrm{BC}$ biosynthesis and consists of four subunits ( $b c s \mathrm{~A}, b c s \mathrm{~B}, b c s \mathrm{C}$, and $b c s \mathrm{D})$. The first gene of the bcs $\mathrm{ABCD}$ operon, $b c s \mathrm{~A}$, encodes the catalytic subunit of cellulose synthase. The second gene, $b c s \mathrm{~B}$, encodes the regulatory subunit of cellulose synthase that binds to c-di-GMP, which plays an important role as the second messenger to activate the cellulose synthesis process [11]. Although the functions of $b c s \mathrm{C}$ and $b c s \mathrm{D}$ have not been completely clarified yet, it has been suggested that $b c s \mathrm{C}$ is responsible for the formation of pores in the membrane to secrete cellulose, as it encodes a protein similar to the proteins involved in the formation of membrane channels or pores [12]. Inactivation of $b c s \mathrm{~A}, b c s B$, or $b c s \mathrm{C}$ completely inhibits $\mathrm{BC}$ synthesis, indicating that these genes are crucial for the biosynthesis. In contrast, the inactivation of $b c s \mathrm{D}$ reduces $\mathrm{BC}$ production by $40 \%$, which suggests that $b c s \mathrm{D}$ is involved in the crystallization of cellulose into nanofibrils [12-14].

Immediately upstream of the $b c s$ operon, two more genes are encoded: cmcax and ccpAx. The endo- $\beta-1,4$-glucanase enzyme, which has cellulose hydrolyzing activity and enhances cellulose synthesis, is encoded by cmcax [15-17]. Based on an electron microscopic analysis, it has been suggested that endo- $\beta-1,4$-glucanase could have an influence on the ribbon assembly. CcpAx is also essential for $\mathrm{BC}$ production and plays a critical role in locating the bcs complex on the cell membrane [15]. It has been suggested that the functions of CcpAx could be related to extracellular transport of cellulose chains from the sites of polymerization within the cell membrane and the crystallization of cellulose fibrils $[18,19]$.

The progress made in $\mathrm{BC}$ production has been extensively discussed and the challenges of commercial scale $\mathrm{BC}$ production have been reviewed in our previous study [20]. Several strategies including the designing of advanced reactors and utilization of various carbon sources have been developed for enhanced production of BC [21]. So far, the most extensively studied bacteria are G. hansenii. However, the challenges in $\mathrm{BC}$ production are mainly related to the strain properties of $G$. hansenii: (1) slow growth compared to many other bacteria (such as E. coli), (2) low productivity, (3) susceptibility to culture conditions, and (4) the spontaneous mutation of cellulose-producing bacteria into cellulose non-producing mutants. Although BC biosynthesis is a highly complex process, novel cellulose-producing strains needs to be developed for enhanced BC production [21, 22].

Escherichia coli, as a well-characterized cell factory, represents a strong candidate for accomplishing BC production in new platforms due to its rapid growth kinetics. $E$. coli $\mathrm{B}$ and $E$. coli $\mathrm{K} 12$ lines are used almost equally as hosts for recombinant protein production. E. coli $\mathrm{BL} 21$, a B line derivative, is one of the most commonly used strains in research. This is due to the fact that BL21 strains are deficient in the production of proteases Lon and OmpT, leading to reduced recombinant protein degradation and higher yields [23-25]. HMS174 (DE3), an engineered successor of the $E$. coli $\mathrm{K}-12$ wild-type, provides a recA1 mutation in a K-12 background. This mutation has a positive effect on plasmid stability [26]. After lysogenization with the DE3 prophage, it became a popular strain for the overexpression of heterologous proteins [27]. However, overexpression of membrane-associated proteins is often toxic to the cells and this can inhibit biomass formation and severely reduce product yields. C41 (DE3), derived from BL21 (DE3), allows high expression of a wide variety of toxic proteins that have previously been difficult or even impossible to express in bacteria [28-30]. The mutations of this strain that were reported to be related to lacUV5 operon or expression of T7 RNA polymerase prevented cell death associated with expression of many toxic recombinant proteins [31].

In this study, simultaneous expression of the bacterial cellulose synthase operon (bcs ABCD) and its upstream operon ( $c m c$ ax and $c c p A x$ ) was performed by co-expression plasmids, $\mathrm{pBCS}$ and $\mathrm{pCMP}$, respectively. The design of the vector constructs compatible with different $E$. coli strains has allowed us the $\mathrm{BC}$ production to be examined in these strains previously mentioned: BL21 (DE3), HMS174 (DE3), and C41 (DE3). Plasmid DNA maintenance and replication commonly create a metabolic burden in E. coli and the response of cells under this energy limiting condition is extremely complex, leading to the alterations of physiology and metabolism of host cells [32]. In return, this results in lower yields of plasmid DNA, particularly a decrease in process outcome. The maintenance of recombinant plasmids is greatly affected by culture conditions [33]. Herein, we developed genetically engineered strains to investigate BC biosynthesis in $E$. coli platforms and examined the effect of temperature and inducer concentration on the plasmid 
stability, the cell growth, and the $\mathrm{BC}$ biosynthesis of these strains.

\section{Materials and methods}

\section{Bacterial strains and plasmids}

Bacterial strains and plasmids used in this study are described in Table 1.

\section{Construction of expression vectors}

The co-expression system was developed using backbones of two compatible Duet Vectors (Novagen): petDuet-1 and pCDFDuet-1. pETDuet-1 has the ColE1 replicon and bla gene for ampicillin/carbenicillin resistance, and pCDFDuet-1 has the CloDF13 replicon and aadA gene for streptomycin resistance. Each of these vectors was designed to express multiple genes and each gene was controlled by a separate T7lac promoter that provides a tight control of the expression by IPTG (isopropyl $\beta$-D-1-thiogalactopyranoside) induction. Each expression unit has own optimal ribosomal binding side located downstream of the promoter. The sequences for cmcax, ccpAx, bcs $\mathrm{A}, b c s \mathrm{~B}, b c s \mathrm{C}$, and $b c s \mathrm{D}$ of $G$. hansenii ATCC 53582 were obtained from literature. Access numbers for the upstream region ( and bcsABCD operon are AB091058 and X54676, respectively [12, 34]. In an effort to enhance the efficiency and accuracy of translation, these target sequences were optimized according to codon usage of $E$. coli by Genewiz, Inc.

Cloning was performed by the restriction digest procedure; $c c p A x$ was cloned into pCDFDuet-1 via 5' using BgIII and $3^{\prime} \mathrm{XhoI}$ as ligation sites, generating the intermediate construct ccpAx_pCDFDuet-1 for the next step. Following that, cmcax was inserted into ccpAx_pCDFDuet-1 via 5' BamHI and 3' Hindlll as ligation sites to create the final construct pCMP (Fig. 1a). The sequences of $b c s \mathrm{~A}$ and $b c s \mathrm{~B}$ were co-inserted into pETDuet-1 via 5' BamHI and 3' AflII to generate the intermediate construct. After that, $b c s \mathrm{C}$ and $b c s \mathrm{D}$ were co-inserted into this intermediate construct via $5^{\prime}$ FseI and 3' XhoI to generate pBCS (Fig. 1b). E. coli strains were then transformed with the constructed plasmids by chemical co-transformation. The selection of transformations was accomplished by plating the cells onto LB agar plates supplemented by $25 \mathrm{mg} / \mathrm{ml}$ carbenicillin and $25 \mathrm{mg} /$ $\mathrm{ml}$ streptomycin (Calbiochem).

\section{Verification of the inserted fragments in PCMP and pBCS}

To verify whether the target fragments were cloned in the correct orientations, the restriction enzyme digestion tests were performed for both plasmids. BamH I and Hind III cleaved pCMP at two edges of the sequences encoding cmcax, and resulted in two linear fragments with the length of 1042 and $4819 \mathrm{bp}$. Mlu I cleaved the pBCS from two sites that were located on the sequences of bcsC and lacI genes, while Xho I cleaved it at the end of the sequence encoding bcsD on this plasmid. These generated three linear fragments with length of 3071, 4304, and $7219 \mathrm{bp}$. The fragments are visualized on agarose gel to detect the DNA bands corresponded to their size. Unrestricted plasmids were also visualized to verify the total size, which also showed bands corresponding to the total

Table 1 Strains and plasmids used in this study

\begin{tabular}{|c|c|c|c|}
\hline Escherichia coli strains & Feature & Synthesized proteins recombinant proteins & Source \\
\hline BL21 (DE3) & Native strain & - & Qiagen \\
\hline GM BL21 (DE3) & Genetically modified strain carrying $\mathrm{pBCS}$ and $\mathrm{pCMP}$ & $\mathrm{Bcs} A, \mathrm{BcsB}, \mathrm{BcsC}, \mathrm{BcsD}, \mathrm{Cmcax}, \mathrm{CcpAx}$ & This study \\
\hline HMS174 (DE3) & Native strain & - & Qiagen \\
\hline GM HMS174 (DE3) & Genetically modified strain carrying $\mathrm{pBCS}$ and $\mathrm{pCMP}$ & $\mathrm{B} c s \mathrm{~A}, \mathrm{BcsB}, \mathrm{BcsC}, \mathrm{BcsD}, \mathrm{Cmcax}, \mathrm{CcpAx}$ & This study \\
\hline C41 (DE3) & Native strain & - & Qiagen \\
\hline GM C41 (DE3) & Genetically modified strain carrying $\mathrm{pBCS}$ and $\mathrm{pCMP}$ & BcsA, BcsB, BcsC, BcsD, Cmcax, CcpAx & This study \\
\hline Plasmids & Feature & Inserted genes & Source \\
\hline pCDFDuet-1 & $\begin{array}{l}\text { Streptomycin resistant plasmid carrying T7/lac promoter and } \\
\text { CloDF13 replicon }\end{array}$ & - & Novagen \\
\hline pETDuet-1 & $\begin{array}{l}\text { Ampicillin resistant plasmid carrying } \mathrm{T} 7 / \mathrm{lac} \text { promoter and } \\
\text { ColE1 replicon }\end{array}$ & - & Novagen \\
\hline pCMP & $\begin{array}{l}\text { Streptomycin resistant plasmid carrying T7/lac promoter for } \\
\text { each inserted gene and CloDF13 replicon }\end{array}$ & cmcax, ссрAx & $\begin{array}{l}\text { This } \\
\text { study }\end{array}$ \\
\hline $\mathrm{pBCS}$ & $\begin{array}{l}\text { Ampicillin resistant plasmid carrying } \mathrm{T} 7 / \mathrm{lac} \text { promoter for each } \\
\text { inserted gene and ColE1 replicon }\end{array}$ & $b c s \mathrm{~A}, b c s \mathrm{~B}, b c s \mathrm{C}, b c s \mathrm{D}$ & $\begin{array}{l}\text { This } \\
\text { study }\end{array}$ \\
\hline
\end{tabular}


Fig. 1 Strategy used for the construction of $\mathrm{pCMP}(\mathbf{a})$ and pBCS (b). pCMP expression unit for the upstream operon (cmcax and cppAx) with $\mathrm{T} 7$ promoter and lac operator, streptomycin resistance region, CloDF13 replicon (CDF ori), lac I region. pBCS expression unit for $b c s$ operon with T7 promoter and lac operator (bcs A, $b c s \mathrm{~B}, b c s \mathrm{C}$, and $b c s \mathrm{C}), \mathrm{f} 1$ replicon, ampicillin resistance region, pBR322-derived ColE1 replicon, lac I region

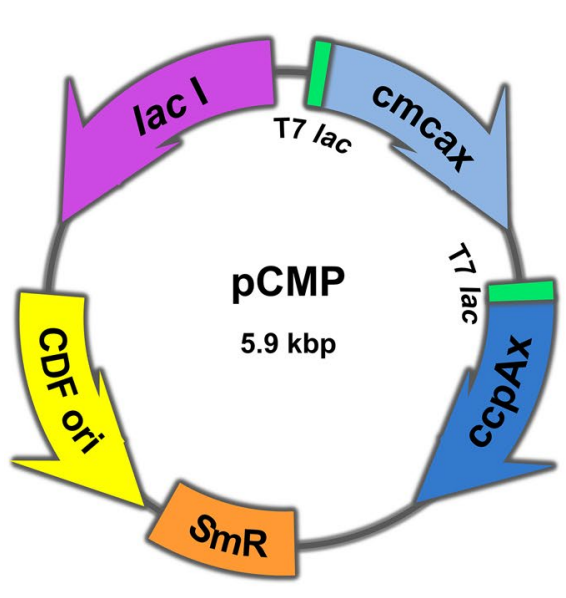

a

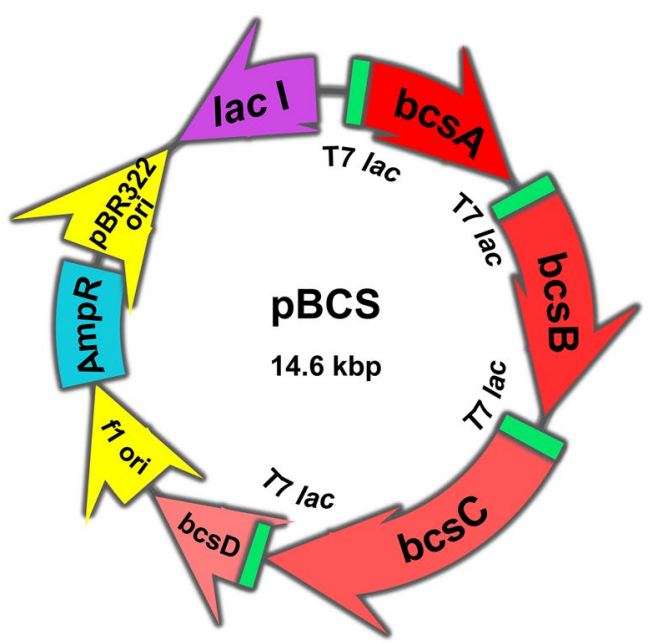

b size of pCMP (5.9 kbp) and pBCS (14.6 kbp) (Online Resource, Fig. ESM1).

\section{Fermentation of genetically modified (GM) E. coli cells}

GM E. coli pre-cultures were cultured in flasks at $37{ }^{\circ} \mathrm{C}$ and $180 \mathrm{rpm}$, in Lysogeny Broth (LB) medium [10 g/L tryptone (Sigma), $5 \mathrm{~g} / \mathrm{L}$ yeast extract (Sigma), $10 \mathrm{~g} / \mathrm{L}$ $\mathrm{NaCl}$ (Sigma)]. The culture media were supplemented by both streptomycin $(50 \mathrm{mg} / \mathrm{ml})$ and carbenicillin $(50 \mathrm{mg} /$ $\mathrm{mL}$ ) for the maintenance of $\mathrm{pCMP}$ and $\mathrm{pBCS}$, respectively. Although pBCS carries a $\beta$-lactamase (bla) gene, which confers resistance to ampicillin, also confers resistance to carbenicillin. Carbenicillin was used in GM cultures, because it tends to be more stable than ampicillin. $4 \mathrm{~g} / \mathrm{L}$ glucose (Sigma) was used as a culture supplement not only to prevent basal expression of recombinant proteins prior to the IPTG induction but also as a carbon source for $\mathrm{BC}$ biosynthesis. The simultaneous expression of recombinant BC proteins in genetically modified (GM) E. coli strains was initiated by inducing the strong T7lac promoter with IPTG. Following the IPTG induction, the culture temperature was shifted to $30^{\circ} \mathrm{C}$ or $22{ }^{\circ} \mathrm{C}$, if necessary. The effect of IPTG induction on plasmid stability and $\mathrm{BC}$ production in each $\mathrm{GM}$ cell line was examined at different culture temperatures $\left(22^{\circ} \mathrm{C}, 30^{\circ} \mathrm{C}\right.$, and $\left.37^{\circ} \mathrm{C}\right)$. The experimental conditions used in this study are summarized in Online Resource, Table ESM1. Optical density (OD) of the cells was measured at $600 \mathrm{~nm}$ using spectrophotometer to monitor cell growth.

\section{Determination of Dry Cell Weight (DCW)}

GM cells were cultured overnight in LB medium at $180 \mathrm{rpm}$ and $37^{\circ} \mathrm{C}$. The cells were then centrifuged at $5000 \times \mathrm{g}$ for $10 \mathrm{~min}$ and washed with distilled water for three times, and $50 \mathrm{ml}$ of cells were re-suspended in $100 \mathrm{ml}$ of distilled water and dried at $80^{\circ} \mathrm{C}$. Cell dry weight $(\mathrm{mg} / \mathrm{ml})$ for each sample was determined. The remaining $50 \mathrm{~mL}$ of cells were used to prepare diluted cell culture samples; $\mathrm{OD}_{600} \mathrm{~nm}$ values of the samples were obtained a spectrophotometer. A calibration curve was prepared by plotting optical density vs. DCW $(\mathrm{g} / \mathrm{L})$.

\section{Plasmid stability test}

Plasmid-harboring GM cells were distinguished from the total viable cells using the plasmid-borne antibiotic resistance. The diluted samples were plated on selective (supplemented with $50 \mathrm{mg} / \mathrm{mL}$ streptomycin and $50 \mathrm{mg} / \mathrm{mL}$ carbenicillin) and non-selective (without antibiotics) LB plates. The colony forming units (cfu) were counted after cultivation at $37^{\circ} \mathrm{C}$ overnight [30]. The percentage of plasmid-harboring colonies among total viable colonies on the plates represents the plasmid stability.

\section{q-PCR assays}

The culture samples were collected at specific time intervals by centrifugation at $10,000 \times g$ for $10 \mathrm{~min}$ at $4{ }^{\circ} \mathrm{C}$. The samples were treated with RNAprotect Bacteria Reagent (Qiagen) to stabilize RNA before extraction of RNA. RNeasy Mini Kit (Qiagen) was used to purify the total RNA. The QuantiTect Reverse Transcription (Qiagen) protocol was followed for the synthesis of cDNA. q-PCR analysis was 
conducted by following QuantiTect SYBR Green Protocol [35]. Total reaction volume was $20 \mu \mathrm{L}$, which contained $12.5 \mathrm{~mL}$ SYBR Green PCR Master Mix, $0.5 \mathrm{~mL}$ of forward primer $(0.3 \mu \mathrm{M})$ and $0.5 \mathrm{~mL}$ of reverse primer $(0.3 \mu \mathrm{M})$ (Invitrogen, UK), $1 \mu \mathrm{l}$ of cDNA (100 ng), and $5.5 \mathrm{~mL}$ of sterile water. q-PCR analysis was conducted in duplicate measurements for each time point. Gradient PCR was performed to select the annealing temperature for the primer pairs. A melting curve was generated for each reaction to ensure the specificity of each PCR product. $\operatorname{ser} \mathrm{C}$ was used as housekeeping gene [36]. Negative controls (no template controls) were used to serve as a general control for nucleic acid contamination and primer dimer formation. The un-induced cells right before the IPTG induction $(T=0)$ as positive controls were used as positive control to monitor the response of the GM cells to IPTG. Then, the data were normalised to the expression levels in positive controls.

The denaturation temperature was set at $95^{\circ} \mathrm{C}$ for $3 \mathrm{~min}$, followed by $95^{\circ} \mathrm{C}$ for $20 \mathrm{~s}$. In the next step, different annealing temperatures were employed in each column of the thermocycler. The annealing temperatures ranged from 58 to $60{ }^{\circ} \mathrm{C}$ for $30 \mathrm{~s}$, and $72{ }^{\circ} \mathrm{C}$ for $30 \mathrm{~s}$. The amplification last for 50 cycles. The oligonucleotide sequences used in this study can be found in Online Resources, Table ESM2.

\section{Extraction of proteins and SDS PAGE analysis}

Periplasmic proteins were extracted by the osmotic shock procedure [37]. In cases where induction with IPTG was needed, GM E. coli cells were grown until the optical density at $600 \mathrm{~nm}$ of the cell culture reached 1.0 and $0.2 \mathrm{mM}$ IPTG was added to culture medium. Grown cells were harvested by centrifugation for $10 \mathrm{~min}$ at $5000 \mathrm{xg}$, $4{ }^{\circ} \mathrm{C}$ and re-suspended in $20 \%$ sucrose solution (w/v) in $30 \mathrm{mM}$ Tris- $\mathrm{HCl}(\mathrm{pH} 8.0)$ with $1 \mathrm{mM}$ ethylenediaminetetraacetic acid (EDTA). Following a second centrifugation at $10,000 \times g$ for $20 \mathrm{~min}$, the pellet was rapidly re-suspended in ice-cold $5 \mathrm{mM} \mathrm{MgCl}_{2}$ and gently incubated for $20 \mathrm{~min}$. Cells were removed from the periplasmic protein extract by centrifugation at $10,000 \times g, 4{ }^{\circ} \mathrm{C}$ for $20 \mathrm{~min}$. Supernatant contained the periplasmic proteins.

The insoluble fractions were extracted by treatments with BugBuster Reagent (Sigma). rLysozym solution was added to a final concentration of $1 \mathrm{KU} / \mathrm{ml}$. The suspension was centrifuged at $5000 \mathrm{~g}$ for $15 \mathrm{~min}$ at $4{ }^{\circ} \mathrm{C}$ to collect the insoluble fraction. After re-suspension of the insoluble fractions in half of the original culture volume of 1:10 diluted BugBuster, the sample was again mixed by vortex and centrifuged as in previous step. This step was repeated a few times. The sample was centrifuged at $16,000 \mathrm{~g}$ for $15 \mathrm{~min}$ at $4{ }^{\circ} \mathrm{C}$ and the supernatant removed. Protein concentrations of the extracted proteins were determined using the method described by Bradford (1976) prior to the SDS PAGE analysis [38].

Protein samples were mixed with $2 \times$ Sample Buffer containing SDS at a 1:1 ratio and boiled for $5 \mathrm{~min}$ to denature the proteins. The marker and the samples were loaded into the wells of $12 \%$ SDS polyacrylamide gels. Separation of proteins based on size was achieved by allowing them to run at $120 \mathrm{~V}$ for approximately $90 \mathrm{~min}$.

\section{Recovery of bacterial cellulose}

Following $24 \mathrm{~h}$ culturing, the cultures first filtered to recover the $\mathrm{BC}$ particles. The samples were treated with $1 \% \mathrm{NaOH}$ solution (w/v) at $70{ }^{\circ} \mathrm{C}$ for $20 \mathrm{~min}$ to remove bacteria and other impurities. The samples were then rinsed with deionized water several times until neutral $\mathrm{pH}$ and then dried in microcentrifuge tubes at $50^{\circ} \mathrm{C}$ to constant weight to obtain dry weight.

\section{Scanning electron microscopy (SEM) analysis}

The morphology and the microstructural features of samples produced by GM $E$. coli strains were investigated using the field-emission scanning electron microscope (FESEM) LEO 1525 (Zeiss, Germany) operating at $5 \mathrm{kV}$. Prior to analysis, samples were dried until constant weight and placed onto double-sided carbon tape mounted onto an aluminum stub. They were gold coated for $2 \mathrm{~min}$ at $20 \mathrm{~mA}$ using an Emitech K575X Peltier (Ashford, UK) cooled sputter coater.

\section{Fourier transform infrared (FTIR) analysis}

FTIR spectroscopy was used to characterize cellulose samples produced by bacteria. ATR-IR spectra were recorded using a Spectrum One FTIR-spectrometer (Perkin Elmer, Massachusetts, USA). The spectra were collected at a resolution of $2 \mathrm{~cm}^{-1}$ in the range of 600 and $4000 \mathrm{~cm}^{-1}$.

\section{Statistical analysis}

Each fermentation was repeated three independent times and each analysis was replicated at three times. Statistical analysis was performed using one-way analysis of variance (ANOVA) and statistical significance was assigned to $P<0.05$.

\section{X-ray diffraction (XRD) analysis}

Crystallographic analysis of the samples was conducted using a Philips X'Pert Pro diffractometer (PANalytical, The Netherlands) equipped with a Nickel-filtered $\mathrm{Cu}-\mathrm{K} \alpha$ radiation $(\lambda=1.5406 \AA)$. The operating voltage and current were $40 \mathrm{kV}$ and $40 \mathrm{~mA}$, respectively. The diffraction spectra were 
collected over a range of $2 \theta$ values from $5^{\circ}$ to $40^{\circ}$ in increments of $0.04^{\circ}$. The relative crystallinity index was calculated by Segal's method [39]:

$C r=100 \times \frac{\left(I_{002}-I_{\mathrm{am}}\right)}{I_{002}}$,

where $I_{002}$ is the peak intensity corresponding to the (110) plane and $\mathrm{I}_{\mathrm{am}}$ is the peak intensity of amorphous fraction at $2 \theta=18^{\circ}$.

\section{Results}

\section{Optimization of IPTG concentration and temperature for $\mathrm{BC}$ biosynthesis}

In plasmid-based expression systems, plasmid replication and maintenance can be easily affected by the inducer concentration and the fermentation temperature. Consequently, these factors can severely affect the process outcome. Appearance of plasmid-free cells is not totally prevented even when antibiotic selection is used, as the concentration of antibiotics often decreases during long-term cultivation as a result of dilution and/or enzymatic degradation by the growing cells [30, 40-43].

All IPTG-induced groups of GM BL21 (DE3) exhibited a dramatic decrease in plasmid stability compared to un-induced GM cells within $1 \mathrm{~h}$ after the induction at both $37^{\circ} \mathrm{C}$ and at $30^{\circ} \mathrm{C}(P<0.05)$ (Online Resource, Fig. ESM2, $\mathrm{a} \& \mathrm{~b})$. The use of elevated growth temperatures $\left(>30^{\circ} \mathrm{C}\right)$ has been previously described as one of the reasons for plasmid instability [44]. However, the final plasmid stability of the induced cells was calculated to be only $5 \%$ at $22{ }^{\circ} \mathrm{C}$ and production of extracellular BC was not detected in GM BL21 (DE3) under any conditions (Online Resource, Fig. ESM2, c).

When induced GM HMS174 (DE3) cells were cultured at $30^{\circ} \mathrm{C}$, the plasmid stability was significantly improved compared that of $37{ }^{\circ} \mathrm{C}$ (Fig. 2a, b). The final percentage of plasmid-bearing cells induced by $0.025 \mathrm{mM}$ IPTG and $0.2 \mathrm{mM}$ IPTG was determined to be 97 and $82 \%$, respectively. Nevertheless, $\mathrm{BC}$ production was not detected at $30^{\circ} \mathrm{C}$. The plasmid stability in this GM strain remained above $85 \%$ at $22{ }^{\circ} \mathrm{C}(0.025 \mathrm{mM}$ IPTG $)$ and BC formation was detected with a concentration of $23.0 \pm 0.02 \mathrm{mg} / \mathrm{L}$ (Fig. 2c). This suggested that the effect of the metabolic stress caused by recombinant protein expression was eliminated by lowering
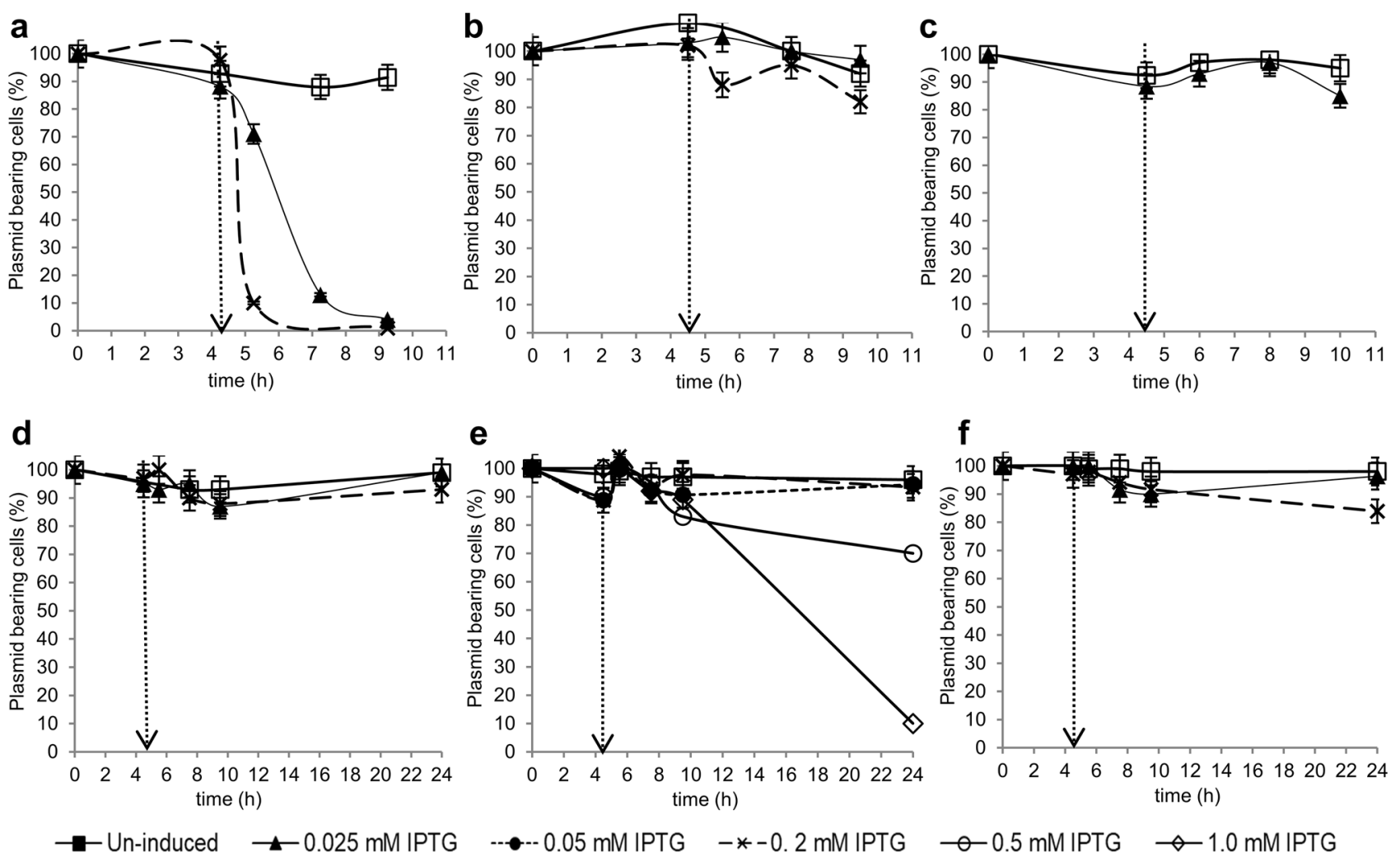

Fig. 2 Effect of IPTG induction on plasmid stability in HMS174 (DE3) at $37{ }^{\circ} \mathrm{C}(\mathbf{a}), 30^{\circ} \mathrm{C}(\mathbf{b})$, and $22{ }^{\circ} \mathrm{C}$ (c), and in GM C41 (DE3) at $37{ }^{\circ} \mathrm{C}$ (c), $30{ }^{\circ} \mathrm{C}(\mathbf{d})$, and $22{ }^{\circ} \mathrm{C}(\mathbf{f})$. The dashed arrows indicate IPTG addition 
both the culture temperature and the IPTG concentration. Therefore, BC biosynthesis in GM C41 (DE3) was investigated at $22{ }^{\circ} \mathrm{C}$ initially (Fig. 2f). The GM C41 (DE3) cells induced by $0.2 \mathrm{mM}$ IPTG produced $8.5 \pm 0.03 \mathrm{mg} / \mathrm{L}$ cellulose ( $83 \%$ plasmid-bearing), while those induced by $0.025 \mathrm{mM}$ IPTG produced $13.5 \pm 0.02 \mathrm{mg} / \mathrm{L}$ ( $96 \%$ plasmidbearing). As C41 (DE3) has been proved previously that it was a superior strain in overexpression of membrane proteins and plasmid stability compared to other $E$. coli strains, higher IPTG concentrations were also examined [28-30]. At $30{ }^{\circ} \mathrm{C}, \mathrm{BC}$ production in the cultures induced by $0.05 \mathrm{mM}$ IPTG and by $0.2 \mathrm{mM}$ IPTG (both $>90 \%$ plasmid-bearing) was $21.0 \pm 0.02 \mathrm{mg} / \mathrm{L}$ and $31.1 \pm 0.03 \mathrm{mg} / \mathrm{L}$, respectively. Increasing the concentration of IPTG to $1.0 \mathrm{mM}$ did not stimulate $\mathrm{BC}$ production, because the plasmid stability dropped dramatically (Fig. 2e). At $37^{\circ} \mathrm{C}$, the final plasmid stability was calculated to be higher than $93 \%$ in both of the induced cultures (Fig. 2d). However, BC production was not observed in any of the GM C41 (DE3) cells cultured above $30^{\circ} \mathrm{C}$ or induced by above $0.2 \mathrm{mM}$ IPTG, proving that high IPTG concentrations/temperatures contribute to the stress level of the host.

The growth kinetics of the induced GM lines was slightly slower compared to the un-induced GM lines at $37^{\circ} \mathrm{C}$. However, lowering the culture temperature (to 30 or $22^{\circ} \mathrm{C}$ ) closed the gap between the growth of the un-induced and the induced groups (data not shown). Dry cell weights (DCW) and product concentrations are presented in Table 2 under the conditions that $\mathrm{BC}$ production was detected. GM C41 (DE3) was identified as the best performer, as it exhibited the highest productivity with $34.3 \pm 0.22 \mathrm{mg}$ cellulose/g cells.

\section{Effect of IPTG concentration on the expression of cmcax, ccpAx, and bcsABCD}

Confirmation of the expression of the recombinant genes (cmcax, ccpAx, bcs $\mathrm{A}, b c s \mathrm{~B}, b c s \mathrm{C}$, and $b c s \mathrm{D}$ ) in $\mathrm{GM}$ cells was performed by q-PCR analysis. For GM BL21 (DE3), all target genes highly expressed even 15 min after IPTG induction (Online Resource, Fig. ESM3, a\&b). The gene expression levels of GM BL21 (DE3) induced by $0.2 \mathrm{mM}$ IPTG were much higher than those induced by $0.025 \mathrm{mM}$ IPTG (Online Resource, Fig. ESM3, c). For an effective expression of membrane proteins, transcription of expression plasmids should be induced slowly with low concentrations of IPTG to prevent accumulating of inactive target proteins [45-48]. Elevated levels of gene expression in GM BL21 (DE3) suggest that BC may not be detected as a result of aggregation of the encoded proteins as inclusion bodies. The expression of recombinant genes in GM BL21 (DE3) was detected even after the dramatic decrease in plasmid stability ( $18 \mathrm{~h}$ ). This could be because the GM cells was retaining only one of the plasmids, which would not allow the expression of the complete target sequence in a single cell for the successful biosynthesis of BC.

Expression of the recombinant genes in GM HMS174 (DE3) was investigated under culture conditions in which BC was detected $\left(0.025 \mathrm{mM}\right.$ IPTG, $\left.22{ }^{\circ} \mathrm{C}\right)$. In contrast to the q-PCR data obtained for BL21 (DE3), the gene expressions in GM HMS174 (DE3) were observed $3 \mathrm{~h}$ after induction at lower but significant levels (between 1.41 and 2.71 fold), which is more desirable to allow the expression of target proteins in an active form (Online Resource, Fig. ESM4, a).

Under the conditions that the highest $\mathrm{BC}$ production detected $\left(30{ }^{\circ} \mathrm{C}, 0.05 \mathrm{mM}\right.$ IPTG) in GM C41 (DE3), the gene expressions $3 \mathrm{~h}$ after IPTG induction were as low as (0.25-2.12 fold) those detected in GM HMS174 (DE3) (Online Resource, Fig. ESM4, b). After $18 \mathrm{~h}$ of induction, $b c s$ genes expressed between 1.61- and 2.19-fold, while upstream genes cmcax and ccpAx expressed 5.02and 3.32-fold, respectively. All target genes expressed at higher levels in the presence of $1.0 \mathrm{mM}$ IPTG compared to those expressed in the presence of $0.05 \mathrm{mM}$ IPTG as expected (Online Resource, Fig. ESM4, c).
Table 2 Dry cell weight (DCW), product concentration $(\mathrm{mg} / \mathrm{L})$, and productivity ( $\mathrm{mg}$ cellulose/g cells) under the conditions that cellulose biosynthesis was detected

\begin{tabular}{|c|c|c|c|c|}
\hline \multirow[t]{3}{*}{ GM HMS174 (DE3) } & \multirow[t]{3}{*}{$22^{\circ} \mathrm{C}$} & & \multicolumn{2}{|l|}{$0.025 \mathrm{mM}$ IPTG } \\
\hline & & DCW $(\mathrm{g} / \mathrm{L})$ & \multicolumn{2}{|l|}{$0.94 \pm 0.05$} \\
\hline & & $\begin{array}{l}\text { Product concentration }(\mathrm{mg} / \mathrm{L}) \\
\text { Productivity (mg cellulose/g cells) }\end{array}$ & \multicolumn{2}{|l|}{$\begin{array}{l}23.0 \pm 0.02 \\
24.5 \pm 0.86\end{array}$} \\
\hline \multirow[t]{7}{*}{ GM C41 (DE3) } & \multirow[t]{3}{*}{$30^{\circ} \mathrm{C}$} & & $0.05 \mathrm{mM}$ IPTG & $0.2 \mathrm{mM}$ IPTG \\
\hline & & $\mathrm{DCW}(\mathrm{g} / \mathrm{L})$ & $0.91 \pm 0.06$ & $0.78 \pm 0.04$ \\
\hline & & $\begin{array}{l}\text { Product concentration }(\mathrm{mg} / \mathrm{L}) \\
\text { Productivity (mg cellulose/g cells) }\end{array}$ & $\begin{array}{l}31.1 \pm 0.03 \\
34.3 \pm 0.22\end{array}$ & $\begin{array}{l}21.0 \pm 0.02 \\
27.4 \pm 0.14\end{array}$ \\
\hline & \multirow[t]{4}{*}{$22{ }^{\circ} \mathrm{C}$} & & $0.025 \mathrm{mM}$ IPTG & $0.2 \mathrm{mM}$ IPTG \\
\hline & & $\mathrm{DCW}(\mathrm{g} / \mathrm{L})$ & $0.90 \pm 0.05$ & $0.85 \pm 0.04$ \\
\hline & & Product concentration $(\mathrm{mg} / \mathrm{L})$ & $8.5 \pm 0.03$ & $13.5 \pm 0.02$ \\
\hline & & Productivity (mg cellulose/g cells) & $9.5 \pm 0.05$ & $15.9 \pm 0.07$ \\
\hline
\end{tabular}




\section{SDS-PAGE analysis of $b c s$ proteins}

$\mathrm{BC}$ is synthetized on the cytoplasmic side of the inner membrane and is transported through the periplasm before being secreted into the extracellular space $[49,50]$. Therefore, $b c s$ proteins are located in periplasm or in cell membrane [19, 49-53]. Membrane proteins are difficult to solubilize and often found in insoluble protein fraction. Therefore, both periplasmic and insoluble fractions of GM cells were analyzed by SDS PAGE. Two protein bands corresponding to the sizes of $\mathrm{BcsC}$ and $\mathrm{BcsD}$ were detected in the insoluble fraction of GM BL21 (DE3), while the other proteins were detected in the periplasmic fraction (Fig. 3a, b). Membrane proteins are often difficult to solubilize and most insoluble protein fractions contain membrane proteins along with inclusion bodies $[54,55]$ Therefore, it is difficult to predict whether $\mathrm{BcsC}$ (an outer membrane protein) detected in insoluble fraction was in a form of aggregation or properly folded. Detection of $\mathrm{BcsD}$ in the insoluble fraction could be the reason for GM BL21 (DE3) not being able to produce $\mathrm{BC}$, as $\mathrm{BcsD}$ is a periplasmic protein that is responsible for the crystallization of $\mathrm{BC}$.

CcpAx and Cmcax were detected slightly above their size region $(4 \mathrm{kDa})$ due to the additional sequences (105 bp including His-tag for cmcax and 96 bp for cppAx) on the cloning sites of pCMP in upstream of these proteins after translation starts. A protein band corresponding to the size of $\mathrm{BcsC}$, an outer membrane protein, was detected in the insoluble fraction of GM HMS174 (DE3) and GM C41(DE3), whereas the other proteins were detected in periplasmic fraction of both (Fig. 3c-f). Clear bands corresponding to the target proteins were detected when GM cells were induced with $0.2 \mathrm{mM}$ IPTG. However, SDS-PAGE analysis did not reveal a significant difference in between the induced fractions and un-induced fractions in the conditions where lower concentrations of IPTG $(0.025,0.05 \mathrm{mM})$ resulted into $\mathrm{BC}$ synthesis (data not shown). The concentration of target proteins could be below the detection limit of SDS-PAGE analysis due to the slow induction, but still well enough to cause the activity.

\section{Direct detection of BC in GM E. coli HMS174 (DE3) and GM C41 (DE3) cell cultures}

Since BC is an extracellular material secreted into the culture medium, it was directly detected $18 \mathrm{~h}$ after the induction in cultures of HMS174 (DE3). In GM C41 (DE3) cultures, $\mathrm{BC}$ production was observed even $3 \mathrm{~h}$ after the induction (Fig. 4b, d). BC production was not found in the cultures of native HMS174 (DE3) and native C41 (DE3) used as negative controls (Fig. 4a, c). The shaking speed is one of the most important parameters that can significantly influence the morphology of BC in cell cultures. Typically, BC produced by $G$. hansenii is in the form of a dense and flat gel-like layer that covers the surface of the culture medium under static condition, which is more preferred to avoid the shear stress generating the mutation of $G$. hansenii into noncellulose-producing state in high agitation [56-58]. Under agitated culture conditions, many particles with various sizes (10 $\mu \mathrm{m}$ to $1 \mathrm{~mm}$ ) and various shapes (spherical, ellipsoidal, fibrous, or stellate) were generated in $\mathrm{BC}$ cultures to form a well-dispersed suspension previously $[57,59,60]$. Here, BC was detected in the form of dispersed fibre-like structures inside the culture media of both GM HMS174 (DE3) and

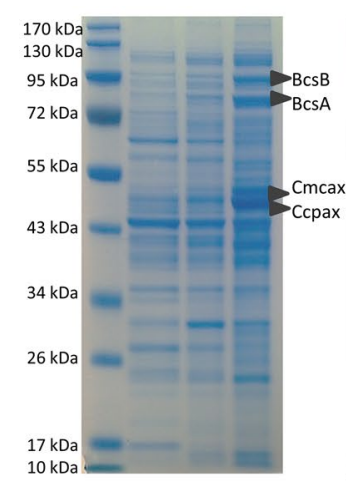

a

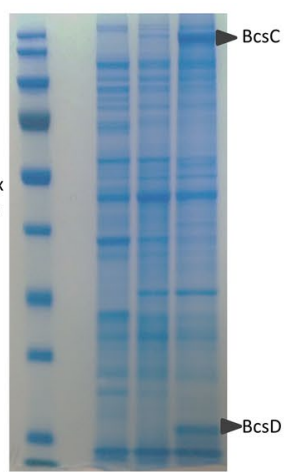

b

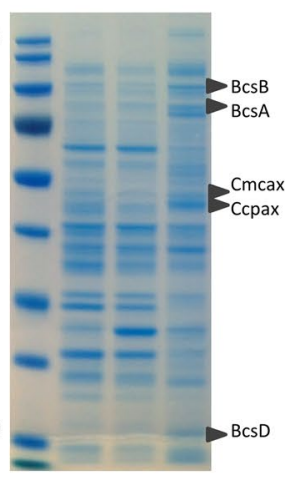

C

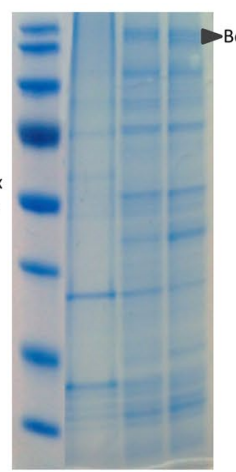

d

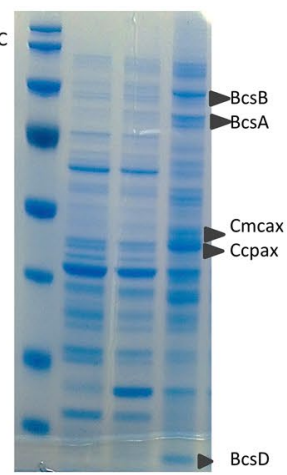

e

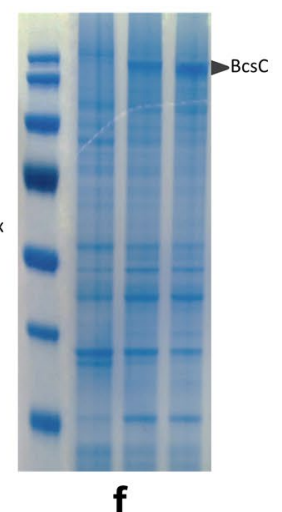

$\mathbf{f}$
Fig. 3 Periplasmic (a) and insoluble (b) fractions of native BL21 and GM BL21 (DE3) induced by $0.2 \mathrm{mM}$ IPTG. For a\&b, Line 1 shows the molecular weight marker, Lines 2, 3, 4 show the extracts of native cells, un-induced GM cells, and induced GM cells (18 h), respectively. Periplasmic (c) and insoluble (d) fractions of native HMS174 (DE3) and GM HMS174 (DE3) induced by $0.2 \mathrm{mM}$ IPTG. For c\&d, Line 1 shows the molecular weight marker, Line 2 shows the extracts of native cells. Lane 3 and Lane 4 show the extracts of induced GM cells collected $3 \mathrm{~h}$ and $18 \mathrm{~h}$ after the induction. Periplasmic (e) and insoluble (f) fractions of native C41 (DE3) and GM C41 (DE3) induced by $0.2 \mathrm{mM}$ IPTG. For e\&f, Line 1 shows the molecular weight marker, Line 2 shows the extracts of native cells. Lane 3 and Lane 4 show the extracts of induced GM cells collected $3 \mathrm{~h}$ and $18 \mathrm{~h}$ after the induction 
Fig. 4 Liquid culture images of native HMS174 (DE3) (a), GM HMS174 (DE3) (b), native C41 (DE3) (c), and GM C41 (DE3) (d). GM strains were cultured at $22^{\circ} \mathrm{C}$ and induced by 0.025 mM IPTG
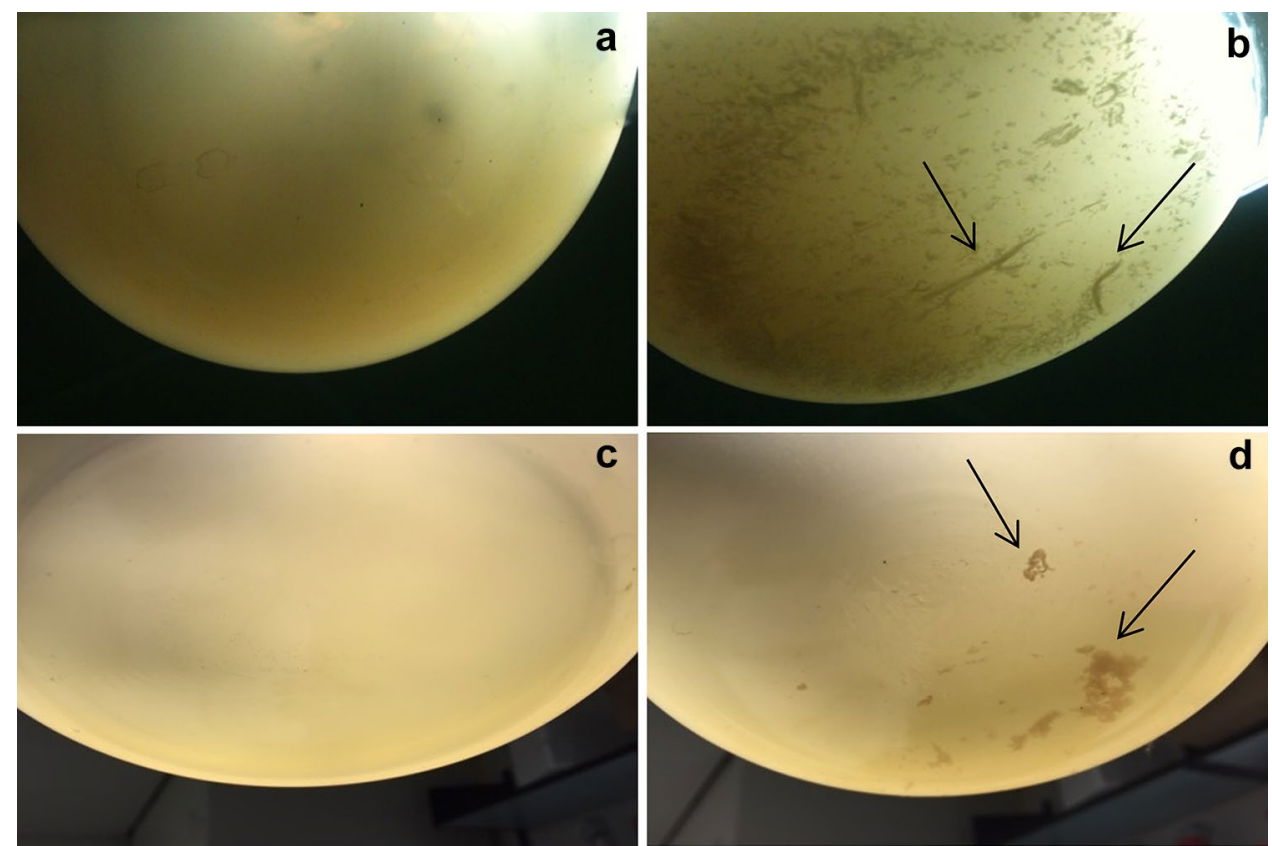

C41 (DE3). A less dense BC was produced by GM strains unlike the structure of original $\mathrm{BC}$ produced under agitated conditions. This was possibly due to the fact that $\mathrm{BC}$ was exposed to the vigorous agitation in GM cultures not only to provide enough oxygen to the cells but also to prevent the cells from precipitating, as E. coli tends to settle to the bottom of cell cultures in the absence of agitation unlike $G$. hansenii.

\section{Morphology characterization of BC}

The morphology of BC produced by GM cells was characterized by SEM and light microscopy. SEM images showed that BC produced by GM HMS174 (DE3) has smooth fibres that formed a dense and random network, which is similar to the general morphology of BC produced by $G$. hansenii (Fig. 5a-c). However, the fibres exhibited an extraordinary structure in terms of size. The lengths of the fibres were approximately between 1000 and $3000 \mu \mathrm{m}$ with diameters ranging from 10 to $20 \mu \mathrm{m}$. The diameter of BC produced by $G$. hansenii is in nanoscale, typically ranging from 10 to $100 \mathrm{~nm}$, while its length can be between 100-several $1000 \mathrm{~nm}[3,61,62]$. The fibres produced by GM HMS174 (DE3) were extremely longer than those in BC typically produced by $G$. hansenii.

BC produced by GM C41 (DE3) shows a more random network and an irregular pattern compared to that of GM HMS174 (DE3) (Fig. 6d-f). It exhibits a biofilm-like structure, which is rigid, but contains fragile connections between cells [63]. Fibres with a length of approximately $500 \mu \mathrm{m}$ were detected on SEM images. Microscope images of BC produced by GM C41 (DE3) revealed more clearly that these fibres are embedded into a biofilm-like structure/ cell-cell interactions and exhibit a very smooth structure with a length of up to $2 \mathrm{~cm}$ (Fig. $5 \mathrm{~g}-\mathrm{i}$ ).

\section{FTIR analysis of BC}

The spectra of BC produced by GM strains are characterized by very strong absorption bands located between 900 and $1243 \mathrm{~cm}^{-1}$ attributed to the $\mathrm{C}-\mathrm{O}$ and $\mathrm{C}-\mathrm{O}-\mathrm{C}$ stretching vibration of glucose (Fig. 6a) [64-67]. The band assigned to the stretching of $-\mathrm{OH}$ groups present in cellulose is identified between 3500 and $3100 \mathrm{~cm}^{-1}$ [68]. The spectral band located between 2800 and $2900 \mathrm{~cm}^{-1}$ is assigned to $\mathrm{C}-\mathrm{H}$ stretching vibrations of $\mathrm{BC}$ (including $-\mathrm{CH} 2$ and -CH3), whereas the spectral bands located between 1420 and $1278 \mathrm{~cm}^{-1}$ are corresponding to the in-plane bending of $\mathrm{C}-\mathrm{H}$ groups $[66,69]$. Cellulose synthesis is correlated with the biofilm formation in E. coli [70-72], which is an extracellular polymeric substance composed of extracellular DNA, proteins, and polysaccharides. Another noticeable region of the spectra appeared around 1517 and $1537 \mathrm{~cm}^{-1}$, which corresponds to amide I groups in this substance [73]. Furthermore, the band at $1640 \mathrm{~cm}^{-1}$ is assigned to $-\mathrm{OH}$ bending.

\section{XRD analysis of BC}

The XRD spectra of BC produced by GM strains are presented in Fig. 6b. BC biosynthesized by G. hansenii ATCC 53582 exhibits the typical spectrum of cellulose I planes, which correspond to [110], [110], and [200] positioned at $14.5^{\circ}, 16.6^{\circ}$, and $22.8^{\circ}$, respectively [74-76]. The spectrum 

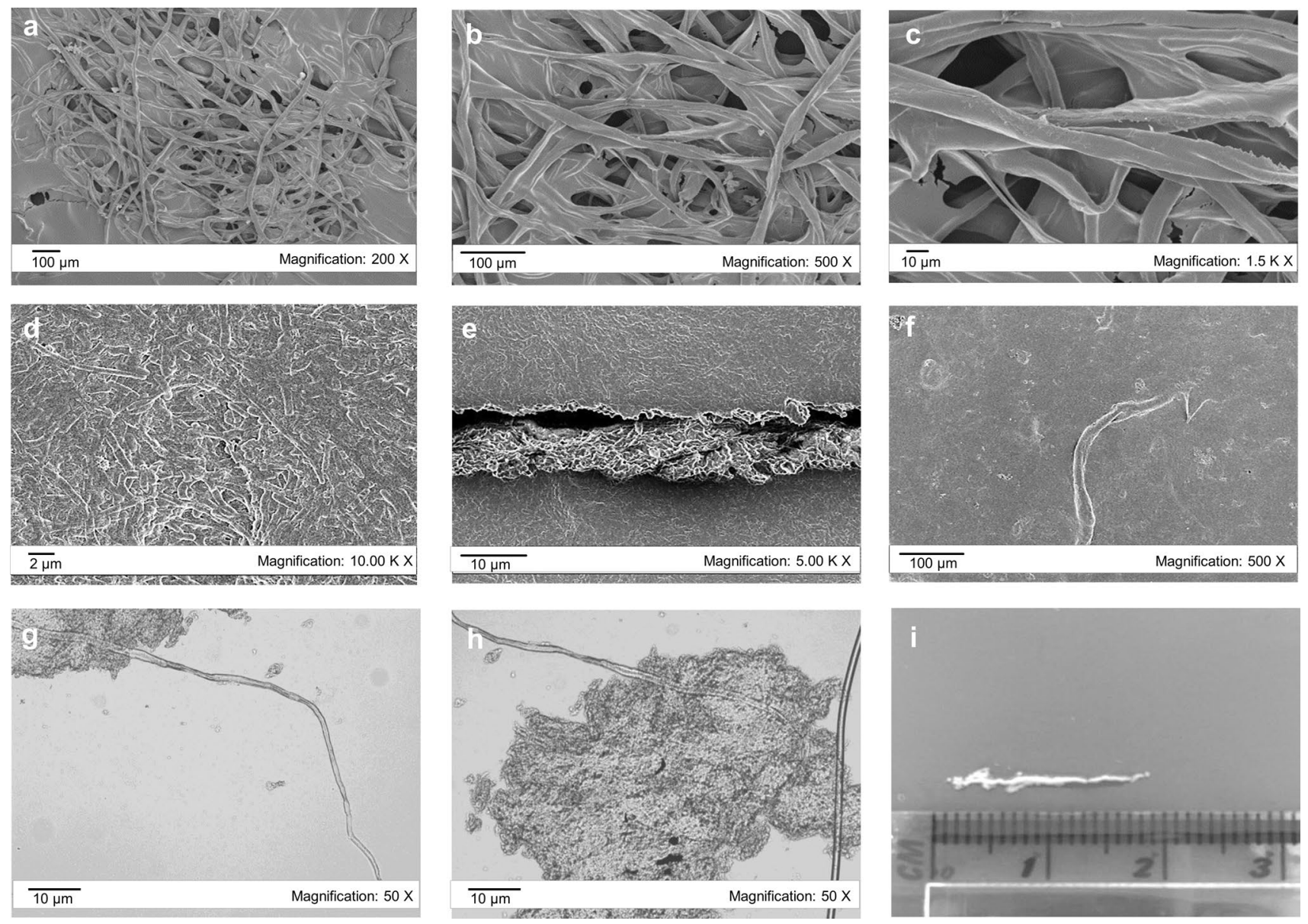

Fig. 5 Scanning electron micrographs showing the microstructure of BC produced by GM HMS174 (DE3) (a-c) and GM C41 (DE3) (d-f) $18 \mathrm{~h}$ after the induction at different resolutions. Light microscope images of $\mathrm{BC}$ fibres and cell aggradations $18 \mathrm{~h}$ after the induction

produced by GM C41 (DE3) induced with $0.05 \mathrm{mM}$ IPTG at different resolutions $(\mathbf{g}, \mathbf{h})$. Length of BC particles that were produced by GM C41 (DE3) under the same conditions (i)

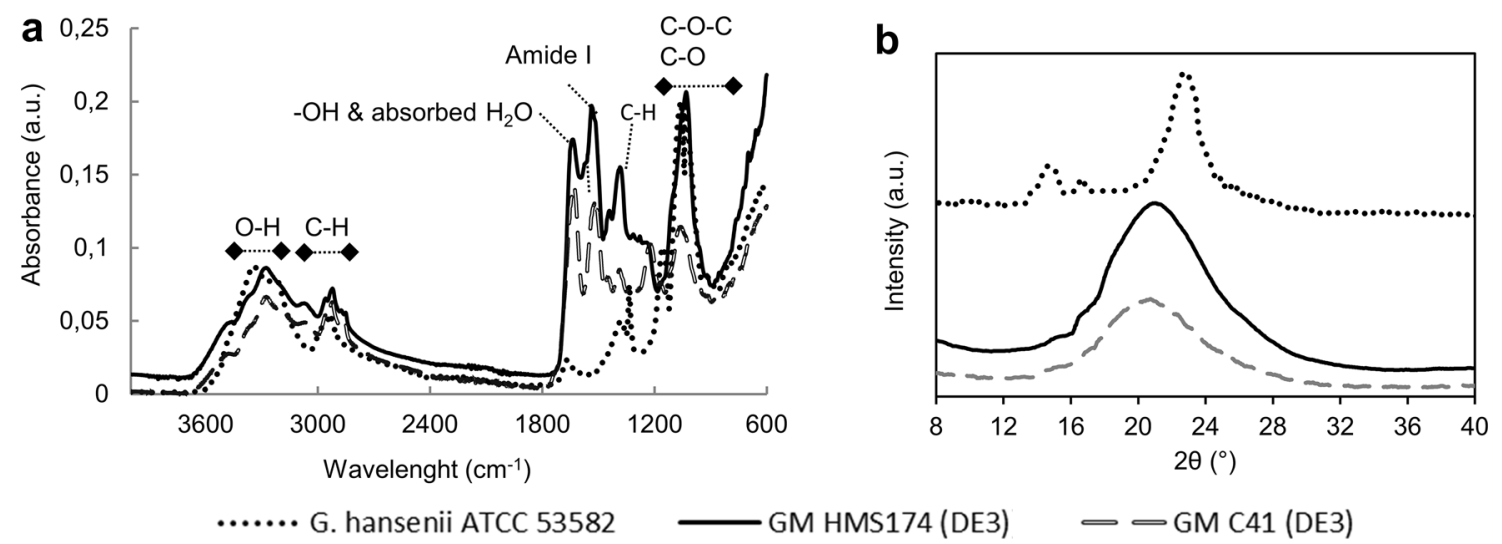

Fig. 6 ATR-FTIR spectra (a) and XRD (b) of BC biosynthesized by G. hansenii ATCC 53582, GM HMS174 (DE3), and GM C41 (DE3)

of $\mathrm{BC}$ produced by GM strains showed one broad band at around $21^{\circ}$ along with two weak peaks at $14.4^{\circ}$ and $16.6^{\circ}$, which exhibited clearly more amorphous structure. The degree of crystallinity of BC biosynthesized by $G$. hansenii ATCC 53582 is estimated to be as high as $85 \%$, while it was estimated to be 47 and $46 \%$ for GM HMS174 (DE3) and 
GM C41 (DE3), respectively. The ratio of the crystalline and amorphous regions depends on various conditions such as cellulose source, microorganism, medium composition, and fermentation conditions [76]. Accordingly, the absence of sharp peaks in XRD spectrum of BC produced by GM may be due to the differences in export mechanisms of bacterial species or to the fermentation conditions.

\section{Discussion}

New cellulose-producing strains have recently been explored by different approaches. It has been shown that the facultative anaerobe Enterobacter sp. FY-07 is able to produce cellulose under aerobic and anaerobic conditions. The gene constitution and arrangement of Enterobacter sp. FY-07 $\mathrm{BC}$ synthesis gene cluster $b c s \mathrm{III}$, comprising $b c s \mathrm{~A}, b c s \mathrm{~B}$, $b c s \mathrm{C}$ and $b c s \mathrm{D}$, are the same as G. hansenii ATCC 53582. This suggests that the same BC synthesis mechanism of $G$. hansenii ATCC 53582 exists in Enterobacter sp. FY-07 [77]. Authors obtained cellulose production also in E. coli DH5 $\alpha$ harboring bcsIII and its upstream; however, the study was focused on BC production in Enterobacter sp. FY-07 and level of BC production in E. coli DH5 $\alpha$ was not examined. When the gene (AKI40_0895) upstream of bcsIII in Enterobacter sp. FY-07 was knocked out, the BC biosynthesis ability of mutant Enterobacter sp. FY-07 ( $\Delta$ hyp) decreased sharply. Similarly, in G. hansenii ATCC 53582, the gene in the location corresponding to AKI40_0895 encodes a cellulose complementing factor (CcpAx), which was also essential for BC production. In another study, bcs genes were constructed using Gibson assembly and transformed into Komagataeibacter xylinus for overexpression [78]. Although there were no significant differences between the growth of wild-type and engineered strains, the engineered $K$. xylinus strains demonstrated faster BC production, generating 2-4-fold higher production compared to wild-type strain. Komagataeibacter rhaeticus, which is also a cellulose-producing strain, has been used to develop a modular genetic toolkit that enables rational reprogramming of the cell for controlled BC production recently [79]. In another study, the reconstitution of cellulose synthase in $E$. coli was investigated [80]. However, this study did not achieve complete BC biosynthesis, since the important proteins for crystallization and localization were not included in the developed system: $\mathrm{BcsC}, \mathrm{BcsD}$, and CcpAx. In addition, no contracts were codon-optimized to eliminate the variations in codon usage between different bacteria in any of these studies, which can have a significant influence on translation efficiency. Here, we included not only $b c s \mathrm{ABCD}$ operon but also its upstream operon in separate vector constructs to test the effect of the operons separately. BC production was not detected when only $b c s \mathrm{ABCD}$ operon was expressed in the initial trials (data not shown).

The recombinant co-expression of complex genetic circuits comes with the cost of low evolutionary stability, especially when most of these proteins are membrane-associated [28, 30, 81, 82]. A number of biological restraints, primarily replication of plasmids and culture conditions, are responsible for limiting the final biomass and the product concentration in such systems. To overcome plasmid instability, genome-based expression systems that integrate the target DNA fragments into the chromosome have been established for $E$. coli ; however, plasmid-based systems are still preferred, because the cloning procedures are simpler and faster for such large DNA sequences [26, 83, 84]. In plasmid-based systems, it is necessary to carefully optimize process conditions for continuous and stable production of a recombinant product.

The metabolic stress caused by the maintenance of recombinant plasmids ultimately resulted in plasmid instability in BL21 (DE3) expression systems previously [40-42]. This phenomenon was observed in also GM BL21 (DE3). Decreasing culture temperature and slow induction of the target genes (with lower IPTG concentrations) have been defined as favorable for recombinant expression systems to prevent inclusion body formation [45-47, 85-87]. However, these were not able to stop the dramatic plasmid loss in GM BL21 (DE3), since the overexpression of multiple membrane proteins in BL21 (DE3) is usually toxic and often results in high overexpression yields [26]. The high gene expression proved by q-PCR in GM BL21 (DE3) supports this theory.

A comparative study demonstrated that HMS174 (DE3) exhibited a high plasmid stability, while a dramatic plasmid loss clearly occurred in BL21 (DE3) [26]. In addition, overexpression of many membrane proteins in BL21 (DE3) was not successful, whereas this was achieved in C41 (DE3) with high plasmid stability previously [28, 29]. Herein, stable expression systems (plasmid stability above $>85 \%$ ) were established in both GM C41 (DE3) and GM HMS174 (DE3) when the bioprocess conditions (temperature and IPTG concentration) were carefully optimized. Both of these GM strains were able to biosynthesize $\mathrm{BC}$ at lower temperature $\left(\leq 30^{\circ} \mathrm{C}\right)$ and lower IPTG concentrations $(\leq 0.2 \mathrm{mM})$. Gene expression levels revealed that the target genes were slowly expressed $3 \mathrm{~h}$ after IPTG induction in these strains. This suggests that the accumulation of inactive proteins may be eliminated by slow induction to allow the production of active proteins $[85,86]$. Due to the absence of significant expression levels of the target protein by SDS-PAGE analysis at low IPTG $(0.025,0.05 \mathrm{mM})$ also supported the possibility of slow expression (data not shown). The BC produced by GM HMS174 (DE3) revealed a notable structure constituted of dense fibres with a length reaching $3000 \mu \mathrm{m}$ with a width ranging between 10 and $20 \mu \mathrm{m}$. The mechanical 
Table 3 Production of BC in static and agitation cultures of G. hansenii ATCC 53582 and GM E. coli strains

\begin{tabular}{llllll}
\hline Strain & Cultivation mode & $\begin{array}{l}\text { Culture time } \\
(\mathrm{h})\end{array}$ & $\begin{array}{l}\text { Volumetric productiv- } \\
\text { ity (mg/L h) }\end{array}$ & $\begin{array}{l}\text { Normalised productiv- } \\
\text { ity (mg/g h) }\end{array}$ \\
\hline G. hansenii ATCC 53,582 & Static & 672 & 9.27 & 0.46 & 0.81 \\
G. hansenii ATCC 53,582 & Static & 168 & 16.25 & 0.92 & {$[93]$} \\
G. hansenii ATCC 53,582 & Static & 168 & 18.45 & 0.80 & {$[92]$} \\
G. hansenii ATCC 53,582 & Agitated & 168 & 16.07 & 0.30 & {$[91]$} \\
G. hansenii ATCC 53,582 & Static/agitated flasks & 168 & 6.00 & 0.44 & {$[34]$} \\
GM E. coli C41 (DE3) & Agitated flasks & 18 & 1.73 & 0.34 & This study \\
GM E. coli HMS174 (DE3) & Agitated flasks & 18 & 1.36 & & This study \\
\hline
\end{tabular}

properties of $\mathrm{BC}$ are affected by the length of the fibres and more importantly the aspect ratio (length/width ratio) of the fibres $[88,89]$. Herein, we produced fibres with high aspect ratio ( $>150)$, which are, therefore, potentially suitable for high efficiency composite materials for various applications as high aspect ratio is desirable for reinforcement $[88,90]$. $\mathrm{BC}$ formation was detected even $3 \mathrm{~h}$ after IPTG induction in GM C41 (DE3) which allows shortening the fermentation time for BC production. The BC obtained previously in agitated cultures of $G$. hansenii exhibited a lower degree of crystallinity compared to that of static cultures [60]. Here, the $\mathrm{BC}$ produced by GM cells showed also a lower degree of crystallization due to the vigorous agitation (180 rpm).

The volumetric productivity of $G$. hansenii ATCC 53582, the donor organism for $b c s$ genes herein, was reported approximately to be between $6.0-18.45 \mathrm{mg} / \mathrm{L} \mathrm{h}$ previously $[34,91-93]$. This is calculated to be $1.73 \mathrm{mg} / \mathrm{L} \mathrm{h}$ for GM $E$. coli $\mathrm{C} 41$ (DE3) and $1.36 \mathrm{mg} / \mathrm{L}$ h for GM E. coli HMS174 (DE3) in our study (Table 3). Although the volumetric productivity appears lower in GM E. coli strains, BC productivities should be reported after normalising to carbon source concentrations in culture media as it highly differs in between $E$. coli and $G$. hansenii cultures $(4 \mathrm{~g} / \mathrm{L}$ glucose supplement in LB medium for GM E. coli cultures and $20 \mathrm{~g} / \mathrm{L}$ of glucose in HS medium for $G$. hansenii cultures). The yield of the cellulose from glucose is calculated to be $0.44 \mathrm{mg} / \mathrm{g} . \mathrm{h}$ in GM E. coli C41 (DE3) and $0.34 \mathrm{mg} / \mathrm{g}$.h in GM E. coli HMS174 (DE3). Both were obtained in the range of normalised productivity of $G$. hansenii ATCC 53582 cultures $(0.30-0.92 \mathrm{mg} / \mathrm{g} \mathrm{h})$. A potent cellulose producer, Gluconacetobacter xylinum BRC5, produced $13.88 \mathrm{mg} / \mathrm{L} \mathrm{h}$ $(0.69 \mathrm{mg} / \mathrm{g} \mathrm{h})$ cellulose in agitated flasks initially [94]. When G. xylinum BRC5 was cultured in fed-batch conditions in a jar bioreactor under both $\mathrm{pH}$ and dissolved $\mathrm{O}_{2}$ control, the volumetric productivity increased significantly and reached to the highest $\mathrm{BC}$ productivity obtained so far with $0.3 \mathrm{~g} / \mathrm{L} \mathrm{h}(15 \mathrm{mg} / \mathrm{g} \mathrm{h})$ [95]. Therefore, volumetric yields in GM strains should be further investigated when using a bioreactor system with an efficient $\mathrm{O}_{2}$ supply and $\mathrm{pH}$ control, as $E$. coli cells grows highly fast when compared to acetic acid bacteria which could potentially result in higher yields. In addition, the fermentation period for GM E. coli strains was only $18 \mathrm{~h}$, whereas it was reported to be around $168 \mathrm{~h}$ for $G$. hansenii cultures, which could be an advantage for the reducing the energy consumption for $\mathrm{BC}$ production processes.

\section{Conclusion}

We achieved recombinant biosynthesis of bacterial cellulose in $E$. coli platforms by the co-expression of $b c s \mathrm{ABCD}$ and its upstream operon. The optimization of bioprocess conditions resulted in the functional and stable biosynthesis of $\mathrm{BC}$ with remarkable fibre structure, as early as $3 \mathrm{~h}$ after the induction. The system developed in this study can be potentially used to contribute to future bioprocess design for bacterial cellulose production by further investigations.

Acknowledgements The authors gratefully acknowledge the financial support of the Turkey National Ministry of Education for funding Gizem Buldum.

Author contributions $\mathrm{GB}$ designed and performed the experiments. $\mathrm{AB}$ designed the $\mathrm{BC}$ analysis experiments. AM designed the experiments. The manuscript was written through contributions of all authors. All authors have given approval to the final version of the manuscript.

\section{Compliance with ethical standards}

Conflict of interest The authors declare that they have no competing interests.

Open Access This article is distributed under the terms of the Creative Commons Attribution 4.0 International License (http://creativecommons.org/licenses/by/4.0/), which permits unrestricted use, distribution, and reproduction in any medium, provided you give appropriate credit to the original author(s) and the source, provide a link to the Creative Commons license, and indicate if changes were made. 


\section{References}

1. Jonas R, Farah LF (1998) Production and application of microbial cellulose. Polym Degrad Stab 59:101-106. https://doi. org/10.1016/s0141-3910(97)00197-3

2. Vandamme EJ, De Baets S, Vanbaelen A, Joris K, De Wulf P (1998) Improved production of bacterial cellulose and its application potential. Polym Degrad Stab 59:93-99. https://doi. org/10.1016/s0141-3910(97)00185-7

3. Klemm D, Heublein B, Fink HP, Bohn A (2005) Cellulose: Fascinating biopolymer and sustainable raw material. Angew Chemie-International Ed 44:3358-3393. https://doi.org/10.1002/ anie. 200460587

4. Helenius J, Brouhard G, Kalaidzidis Y, Diez S, Howard J (2006) The depolymerizing kinesin MCAK uses lattice diffusion to rapidly target microtubule ends. Nature 441:115-119. https:// doi.org/10.1038/nature04736

5. Hutchens SA, Benson RS, Evans BR, O'Neill HM, Rawn CJ (2006) Biomimetic synthesis of calcium-deficient hydroxyapatite in a natural hydrogel. Biomaterials 27:4661-4670. https:// doi.org/10.1016/j.biomaterials.2006.04.032

6. Fontana JD, De Souza AM, Fontana CK, Torriani IL, Moreschi JC, Gallotti BJ, De Souza SJ, Narcisco GP, Bichara JA, Farah LFX (1990) Acetobacter cellulose pellicle as a temporary skin substitute. Appl Biochem Biotechnol 24-25:253-264. https:// doi.org/10.1007/BF02920250

7. Czaja W, Krystynowicz A, Bielecki S, Brown RM (2006) Microbial cellulose - the natural power to heal wounds. Biomaterials 27:145-151. https://doi.org/10.1016/j.biomaterials.2005.07.035

8. Brown RM (1999) Cellulose structure and biosynthesis. Pure Appl Chem 71:767-775. https://doi.org/10.1351/ pac199971050767

9. Thomas S (2013) Handbook of biopolymer-based materials : from blends and composites to gels and complex networks

10. Bielecki S, Krystynowicz A, Turkiewicz M, Kalinowska H (2005) Bacterial cellulose, WILEY-VCH Verlag GMBH \& Co. KGaA,

11. Wong HC, Fear AL, Calhoon RD, Eichinger GH, Mayer R, Amikam D, Benziman M, Gelfand DH, Meade JH, Emerick AW, Bruner R, Benbassat A, Tal R (1990) Genetic organization of the cellulose synthase operon in Acetobacter xylinum. Proc Natl Acad Sci U S A 87:8130-8134. https://doi.org/10.1073/pnas.87.20.8130

12. Saxena IM, Kudlicka K, Okuda K, Brown RM (1994) Characterization of genes in the cellulose-synthesizing operon (acs operon) of Acetobacter xylinum - implications for cellulose crystallization. J Bacteriol 176:5735-5752

13. Brown RM, Saxena IM (2000) Cellulose biosynthesis: A model for understanding the assembly of biopolymers. Plant Physiol Biochem 38:57-67. https://doi.org/10.1016/s0981-9428(00)00168-6

14. Hu S-Q, Gao Y-G, Tajima K, Sunagawa N, Zhou Y, Kawano S, Fujiwara T, Yoda T, Shimura D, Satoh Y, Munekata M, Tanaka I, Yao M (2010) Structure of bacterial cellulose synthase subunit D octamer with four inner passageways. Proc Natl Acad Sci 107:17957-17961. https://doi.org/10.1073/pnas.1000601107

15. Standal R, Iversen TG, Coucheron DH, Fjaervik E, Blatny JM, Valla $S$ (1994) A new gene required for cellulose production and a gene encoding cellulolytic activity in Acetobacter xylinum are colocalized with the bcs operon. J Bacteriol 176:665-672

16. Tonouchi N, Thara N, Tsuchida T, Yoshinaga F, Beppu T, Horinouchi S (1995) Addition of a small amount of an endoglucanase enhances cellulose production by Acetobacter xylinum. Biosci Biotechnol Biochem 59:805-808

17. Koo HM, Song SH, Pyun YR, Kim YS (1998) Evidence that a beta-1,4-endoglucanase secreted by Acetobacter xylinum plays an essential role for the formation of cellulose fiber. Biosci Biotechnol Biochem 62:2257-2259. https://doi.org/10.1271/bbb.62.2257
18. Sunagawa N, Tajima K, Hosoda M, Kawano S, Kose R, Satoh Y, Yao M, Dairi T (2012) Cellulose production by Enterobacter sp CJF-002 and identification of genes for cellulose biosynthesis. Cellulose 19:1989-2001. https://doi.org/10.1007/ s10570-012-9777-2

19. Sunagawa N, Fujiwara T, Yoda T, Kawano S, Satoh Y, Yao M, Tajima K, Dairi T (2013) Cellulose complementing factor (Ccp) is a new member of the cellulose synthase complex (terminal complex) in Acetobacter xylinum. J Biosci Bioeng 115:607-612. https://doi.org/10.1016/j.jbiosc.2012.12.021

20. Lee KY, Buldum G, Mantalaris A, Bismarck A (2014) More than meets the eye in bacterial cellulose: biosynthesis, bioprocessing, and applications in advanced fiber composites. Macromol Biosci 14:10-32

21. Islam MU, Ullah MW, Khan S, Shah N, Park JK (2017) Strategies for cost-effective and enhanced production of bacterial cellulose. Int J Biol Macromol 102:1166-1173. https://doi.org/10.1016/j. ijbiomac.2017.04.110

22. Chawla PR, Bajaj IB, Survase SA, Singhal RS (2009) Microbial cellulose: fermentative production and applications. Food Technol Biotechnol 47:107-124

23. Gottesman S (1989) Genetics of proteolysis in Escherichia coli*. Annu Rev Genet 23:163-198. https://doi.org/10.1146/annurev. ge.23.120189.001115

24. Gottesman S (1996) Proteases and their targets in Escherichia coli. Annu Rev Genet 30:465-506. https://doi.org/10.1146/annurev. genet.30.1.465

25. Shiloach J, Kaufman J, Guillard AS, Fass R (1996) Effect of glucose supply strategy on acetate accumulation, growth, and recombinant protein production by Escherichia coli BL21 (lambdaDE3) and Escherichia coli JM109. Biotechnol Bioeng 49:421-428. https://doi.org/10.1002/ (sici)1097-0290(19960220)49:4<421::aid-bit9>3.0.co;2-r

26. Marisch K, Bayer K, Cserjan-Puschmann M, Luchner M, Striedner G (2013) Evaluation of three industrial Escherichia coli strains in fed-batch cultivations during high-level SOD protein production. Microb Cell Fact 12:58. https://doi.org/10.1186/1475-2859-12-58

27. Mairhofer J, Krempl PM, Thallinger GG, Striedner G Finished Genome Sequence of Escherichia coli K-12 Strain HMS174 (ATCC 47011). Genome Announc, 2

28. Miroux B, Walker JE (1996) Over-production of proteins in Escherichia coli: mutant hosts that allow synthesis of some membrane proteins and globular proteins at high levels. J Mol Biol 260:289-298. https://doi.org/10.1006/jmbi.1996.0399

29. Wagner S, Baars L, Ytterberg AJ, Klussmeier A, Wagner CS, Nord O, Nygren PA, van Wijk KJ, de Gier JW (2007) Consequences of membrane protein overexpression in Escherichia coli. Mol Cell Proteomics 6:1527-1550. https://doi.org/10.1074/mcp. M600431-MCP200

30. Dumon-Seignovert L, Cariot G, Vuillard L (2004) The toxicity of recombinant proteins in Escherichia coli: a comparison of overexpression in BL21(DE3), C41(DE3), and C43(DE3). Protein Expr Purif 37:203-206. https://doi.org/10.1016/j.pep.2004.04.025

31. Wagner S, Klepsch MM, Schlegel S, Appel A, Draheim R, Tarry M, Högbom M, van Wijk KJ, Slotboom DJ, Persson JO, de Gier J-W (2008) Tuning Escherichia coli for membrane protein overexpression. Proc Natl Acad Sci 105:14371-14376. https://doi. org/10.1073/pnas.0804090105

32. Sorensen HP, Mortensen KK (2005) Advanced genetic strategies for recombinant protein expression in Escherichia coli. J Biotechnol 115:113-128. https://doi.org/10.1016/j.jbiotec.2004.08.004

33. Goyal A, Prasad KN, Prasad A, Gupta S, Ghoshal U, Ayyagari A (2009) Extended spectrum beta-lactamases in Escherichia coli \& Klebsiella pneumoniae \& associated risk factors. Indian J Med Res 129:695-700 
34. Kawano S, Tajima K, Uemori Y, Yamashita H, Erata T, Munekata M, Takai M (2002) Cloning of cellulose synthesis related genes from Acetobacter xylinum ATCC23769 and ATCC53582: Comparison of cellulose synthetic ability between strains. DNA Res 9:149-156. https://doi.org/10.1093/dnares/9.5.149

35. Qiagen (2011) QuantiTect ${ }^{\circledR}$ SYBR $®$ Green PCR Handbook. In: Sample Assay Technol. https://www.qiagen.com/ us/resources/resourcedetail id $=38083588-73 \mathrm{db}-4 \mathrm{~d} 2 \mathrm{e}-9 \mathrm{ed} 2$ 9f66b154ab3e\&lang=en.Accessed 21 Oct 2017

36. Herold S, Siebert J, Huber A, Schmidt H (2005) Global expression of prophage genes in Escherichia coli O157:H7 strain EDL933 in response to norfloxacin. Antimicrob Agents Chemother 49:931944. https://doi.org/10.1128/aac.49.3.931-944.2005

37. Nossal NG, Heppel LA (1966) The release of enzymes by osmotic shock from Escherichia coli in Exponential Phase. J Biol Chem 241:3055-3062

38. Bradford MM (1976) A rapid and sensitive method for the quantitation of microgram quantities of protein utilizing the principle of protein-dye binding. Anal Biochem 72:248-254. https://doi. org/10.1016/0003-2697(76)90527-3

39. Segal L, Creely JJ, Martin AE, Conrad CM (1959) An empirical method for estimating the degree of crystallinity of native cellulose using the X-ray diffractometer. Text Res J 29:786-794. https://doi.org/10.1177/004051755902901003

40. Collins T, Azevedo-Silva J, da Costa A, Branca F, Machado R, Casal M (2013) Batch production of a silk-elastin-like protein in E. coli BL21(DE3): key parameters for optimisation. Microb Cell Fact 12:21. https://doi.org/10.1186/1475-2859-12-21

41. Yu H, Shi Y, Sun X, Luo H, Shen Z (2003) Effect of poly(betahydroxybutyrate) accumulation on the stability of a recombinant plasmid in Escherichia coli. J Biosci Bioeng 96:179-183

42. Zhao J-B, Wei D-Z (2007) Use of a derivative of Escherichia coli BL21(DE3) for Efficient production of three different recombinant proteins. Biotechnol Prog 23:1043-1048. https://doi.org/10.1021/ bp070155b

43. Balbás P (2001) Understanding the art of producing protein and nonprotein molecules in Escherichia coli. Mol Biotechnol 19:251-267 https://doi.org/10.1385/MB:19:3:251

44. Corchero JL, Villaverde A (1998) Plasmid maintenance in Escherichia coli recombinant cultures is dramatically, steadily, and specifically influenced by features of the encoded proteins. Biotechnol Bioeng 58:625-632

45. Sevastsyanovich Y, Alfasi S, Overton T, Hall R, Jones J, Hewitt C, Cole J (2009) Exploitation of GFP fusion proteins and stress avoidance as a generic strategy for the production of high-quality recombinant proteins. FEMS Microbiol Lett 299:86-94

46. Wood TK, Peretti SW (1991) Effect of chemically-induced, cloned-gene expression on protein synthesis in E. Coli Biotechnol Bioeng 38:397-412. https://doi.org/10.1002/bit.260380410

47. Donovan RS, Robinson CW, Glick BR (1996) Review: Optimizing inducer and culture conditions for expression of foreign proteins under the control of thelac promoter. J Ind Microbiol 16:145-154. https://doi.org/10.1007/BF01569997

48. Overton TW (2014) Recombinant protein production in bacterial hosts. Drug Discov Today 19:590-601. https://doi.org/10.1016/j. drudis.2013.11.008

49. Morgan JLW, Strumillo J, Zimmer J (2013) Crystallographic snapshot of cellulose synthesis and membrane translocation. Nature 493:181-186

50. Augimeri RV, Strap JL (2015) The phytohormone ethylene enhances cellulose production, regulates crp/fnrkx transcription and causes differential gene expression within the bacterial cellulose synthesis operon of Komagataeibacter (Gluconacetobacter) xylinus ATCC 53582. Front Microbiol 6:1459

51. De Ley J, Gillis M, Swings J (1984) Family VI. Acetobacteraceae. Bergey's Maual Syst. Bacteriol,
52. Omadjela O, Narahari A, Strumillo J, Mélida H, Mazur O, Bulone $\mathrm{V}$, Zimmer J (2013) BcsA and BcsB form the catalytically active core of bacterial cellulose synthase sufficient for in vitro cellulose synthesis. Proc Natl Acad Sci USA 110:17856-17861. https://doi. org/10.1073/pnas.1314063110

53. Yasutake Y, Kawano S, Tajima K, Yao M, Satoh Y, Munekata M, Tanaka I (2006) Structural characterization of the Acetobacter xylinum endo- $\beta$-1,4-glucanase CMCax required for cellulose biosynthesis. Proteins Struct Funct Bioinforma 64:1069-1077. https://doi.org/10.1002/prot.21052

54. Bannwarth M, Schulz GE (2003) The expression of outer membrane proteins for crystallization. Biochim Biophys Acta - Biomembr 1610:37-45. https://doi.org/10.1016/ S0005-2736(02)00711-3

55. Korepanova A, Gao FP, Hua Y, Qin H, Nakamoto RK, Cross TA (2005) Cloning and expression of multiple integral membrane proteins from Mycobacterium tuberculosis in Escherichia coli. Protein Sci 14:148-158. https://doi.org/10.1110/ps.041022305

56. Tsouko E, Kourmentza C, Ladakis D, Kopsahelis N, Mandala I, Papanikolaou S, Paloukis F, Alves V, Koutinas A (2015) Bacterial cellulose production from industrial waste and by-product streams. Int J Mol Sci 16:14832-14849. https://doi.org/10.3390/ ijms 160714832

57. Dudman WF (1960) Cellulose production by Acetobacter acetigenum in defined medium. J Gen Microbiol 21:327-337

58. Valla S, Kjosbakken J (1982) ellulose-negative mutants of Acetobacter xylinum. J Gen Microbiol 128:1401-1408

59. Hestrin S, Schramm M (1954) Synthesis of cellulose by Acetobacter xylinum. 2. Preparation of freeze-dried cells capable of polymerizing glucose to cellulose. Biochem J 58:345-352

60. Watanabe K, Tabuchi M, Morinaga Y, Yoshinaga F (1998) Structural Features and properties of bacterial cellulose produced in agitated culture. Cellulose 5:187-200. https://doi.org/10.102 3/A:1009272904582

61. Ross P, Mayer R, Benziman M (1991) cellulose biosynthesis and function in bacteria. Microbiol Rev 55:35-58

62. Haigler CH, White AR, Brown RM, Cooper KM (1982) Alteration of in vivo cellulose ribbon assembly by carboxymethylcellulose and other cellulose derivatives. J Cell Biol 94:64-69. https://doi. org/10.1083/jcb.94.1.64

63. Romling U, Rohde M, Olsen A, Normark S, Reinkoster J (2000) AgfD, the checkpoint of multicellular and aggregative behaviour in Salmonella typhimurium regulates at least two independent pathways. Mol Microbiol 36:10-23

64. Wong S-S, Kasapis S, Tan YM (2009) Bacterial and plant cellulose modification using ultrasound irradiation. Carbohydr Polym 77:280-287. https://doi.org/10.1016/j.carbpol.2008.12.038

65. Oh SY, Yoo DI, Shin Y, Kim HC, Kim HY, Chung YS, Park WH, Youk JH (2005) Crystalline structure analysis of cellulose treated with sodium hydroxide and carbon dioxide by means of X-ray diffraction and FTIR spectroscopy. Carbohydr Res 340:2376-2391. https://doi.org/10.1016/j.carres.2005.08.007

66. Carrillo F, Colom X, Suñol JJ, Saurina J (2004) Structural FTIR analysis and thermal characterisation of lyocell and viscose-type fibres. Eur Polym J 40:2229-2234. https://doi.org/10.1016/j. eurpolymj.2004.05.003

67. Kacurakova M, Smith AC, Gidley MJ, Wilson RH (2002) Molecular interactions in bacterial cellulose composites studied by 1D FT-IR and dynamic 2D FT-IR spectroscopy. Carbohydr Res 337:1145-1153

68. Huang HC, Chen LC, Lin SB, Hsu CP, Chen HH (2010) In situ modification of bacterial cellulose network structure by adding interfering substances during fermentation. Bioresour Technol 101:6084-6091. https://doi.org/10.1016/j.biortech.2010.03.031

69. Łojewska J, Miśkowiec P, Łojewski T, Proniewicz LM (2005) Cellulose oxidative and hydrolytic degradation: In situ FTIR 
approach. Polym Degrad Stab 88:512-520. https://doi. org/10.1016/j.polymdegradstab.2004.12.012

70. Zogaj X, Nimtz M, Rohde M, Bokranz W, Romling U (2001) The multicellular morphotypes of Salmonella typhimurium and Escherichia coli produce cellulose as the second component of the extracellular matrix. Mol Microbiol 39:1452-1463

71. Romling U (2002) Molecular biology of cellulose production in bacteria. Res Microbiol 153:205-212. https://doi.org/10.1016/ s0923-2508(02)01316-5

72. Da Re S, Ghigo JM (2006) A CsgD-independent pathway for cellulose production and biofilm formation in Escherichia coli. J Bacteriol 188:3073-3087. https://doi.org/10.1128/ jb.188.8.3073-3087.2006

73. Jiao Y, Cody GD, Harding AK, Wilmes P, Schrenk M, Wheeler KE, Banfield JF, Thelen MP (2010) Characterization of extracellular polymeric substances from acidophilic microbial biofilms. Appl Environ Microbiol 76:2916-2922. https://doi.org/10.1128/ AEM.02289-09

74. Poletto M, Pistor V, Zattera AJ (2013) Structural characteristics and thermal properties of native cellulose. InTech, Rijeka, Ch. 0

75. Ullah H, Wahid F, Santos HA, Khan T (2016) Advances in biomedical and pharmaceutical applications of functional bacterial cellulose-based nanocomposites. Carbohydr Polym 150:330-352. https://doi.org/10.1016/j.carbpol.2016.05.029

76. Shezad O, Khan S, Khan T, Park JK (2010) Physicochemical and mechanical characterization of bacterial cellulose produced with an excellent productivity in static conditions using a simple fedbatch cultivation strategy. Carbohydr Polym 82:173-180. https:// doi.org/10.1016/j.carbpol.2010.04.052

77. Ji K, Wang W, Zeng B, Chen S, Zhao Q, Chen Y, Li G, Ma T (2016) Bacterial cellulose synthesis mechanism of facultative anaerobe Enterobacter sp. FY-07. Sci Rep 6:21863

78. Mangayil R, Rajala S, Pammo A, Sarlin E, Luo J, Santala V, Karp M, Tuukkanen S (2017) Engineering and characterization of bacterial nanocellulose films as low cost and flexible sensor material. ACS Appl Mater Interfaces 9:19048-19056. https://doi. org/10.1021/acsami.7b04927

79. Florea M, Hagemann H, Santosa G, Abbott J, Micklem CN, Spencer-Milnes X, de Arroyo Garcia L, Paschou D, Lazenbatt C, Kong D, Chughtai H, Jensen K, Freemont PS, Kitney R, Reeve B, Ellis T (2016) Engineering control of bacterial cellulose production using a genetic toolkit and a new cellulose-producing strain. Proc Natl Acad Sci 113:E3431-E3440. https://doi.org/10.1073/ pnas. 1522985113

80. Imai T, Sun SJ, Horikawa Y, Wada M, Sugiyama J (2014) Functional reconstitution of cellulose synthase in Escherichia coli. Biomacromolecules 15:4206-4213. https://doi.org/10.1021/ bm501217g

81. Drew D, Froderberg L, Baars L, de Gier JW (2003) Assembly and overexpression of membrane proteins in Escherichia coli. Biochim Biophys Acta 1610:3-10

82. Sleight SC, Bartley BA, Lieviant JA, Sauro HM (2010) Designing and engineering evolutionary robust genetic circuits. J Biol Eng 4:12. https://doi.org/10.1186/1754-1611-4-12
83. Striedner G, Pfaffenzeller I, Markus L, Nemecek S, Grabherr R, Bayer K (2010) Plasmid-free T7-based Escherichia coli expression systems. Biotechnol Bioeng 105:786-794. https://doi. org/10.1002/bit.22598

84. Heap JT, Ehsaan M, Cooksley CM, Ng Y-K, Cartman ST, Winzer $\mathrm{K}$, Minton NP (2012) Integration of DNA into bacterial chromosomes from plasmids without a counter-selection marker. Nucleic Acids Res 40:e59-e59. https://doi.org/10.1093/nar/gkr1321

85. Dormiani K, Khazaie Y, Sadeghi HM, Rabbani M, Moazen F (2007) Cloning and expression of a human tissue plasminogen activator variant: K2S in Escherichia coli. Pak J Biol Sci 10:946-949

86. Vera A, Gonzalez-Montalban N, Aris A, Villaverde A (2007) The conformational quality of insoluble recombinant proteins is enhanced at low growth temperatures. Biotechnol Bioeng 96:1101-1106. https://doi.org/10.1002/bit.21218

87. Silva F, Passarinha L, Sousa F, Queiroz JA, Domingues FC (2009) Influence of growth conditions on plasmid DNA production. J Microbiol Biotechnol 19:1408-1414

88. Eichhorn SJ, Dufresne A, Aranguren M, Marcovich NE, Capadona JR, Rowan SJ, Weder C, Thielemans W, Roman M, Renneckar S, Gindl W, Veigel S, Keckes J, Yano H, Abe K, Nogi M, Nakagaito AN, Mangalam A et al (2010) Review: current international research into cellulose nanofibres and nanocomposites. J Mater Sci 45:1-33. https://doi.org/10.1007/s10853-009-3874-0

89. Kuboki T, Lee YH, Park CB, Sain M (2009) Mechanical properties and foaming behavior of cellulose fiber reinforced highdensity polyethylene composites. Polym Eng Sci 49:2179-2188. https://doi.org/10.1002/pen.21464

90. Pickering KL, Efendy MGA, Le TM (2016) A review of recent developments in natural fibre composites and their mechanical performance. Compos Part A Appl Sci Manuf 83:98-112. https:// doi.org/10.1016/j.compositesa.2015.08.038

91. Czaja W, Romanovicz D, Brown R malcolm (2004) Structural investigations of microbial cellulose produced in stationary and agitated culture. Cellulose 11:403-411. https://doi. org/10.1023/B:CELL.0000046412.11983.61

92. Fang L, Catchmark JM (2015) Characterization of cellulose and other exopolysaccharides produced from Gluconacetobacter strains. Carbohydr Polym 115:663-669. https://doi.org/10.1016/j. carbpol.2014.09.028

93. Ishihara M, Matsunaga M, Hayashi N, Tišler V (2002) Utilization of d-xylose as carbon source for production of bacterial cellulose. Enzyme Microb Technol 31:986-991. https://doi.org/10.1016/ S0141-0229(02)00215-6

94. Yang YK, Park SH, Hwang JW, Pyun YR, Kim YS (1998) Cellulose production by Acetobacter xylinum BRC5 under agitated condition. J Ferment Bioeng 85:312-317. https://doi.org/10.1016/ S0922-338X(97)85681-4

95. Hwang JW, Yang YK, Hwang JK, Pyun YR, Kim YS (1999) Effects of $\mathrm{pH}$ and dissolved oxygen on cellulose production by Acetobacter xylinum BRC5 in agitated culture. J Biosci Bioeng 88:183-188. https://doi.org/10.1016/s1389-1723(99)80199-6 